\title{
濃染剤の染色に及ぼす効果
}

（第 4 報）非イオン活性剤の濃染効果に及ぼす水の影響

$\begin{array}{cccccc}\text { 京都工芸繊維学 工芸学部 } & \text { 橋 } & \text { 本 } & & \text { 勇 (会員) } \\ " \text { " } & \text { 今 } & \text { 井 義 彦 } & \end{array}$

\section{Effect of $\mathbb{D}$ ye Promoting Agents on $\mathbb{D}$ yeing.}

\section{Part 4 : Effect of Water on the Dye Promoting Efficiency of Noniomic Surfactants.}

\author{
Isamu Hashimoto and Yoshihiko Imai, \\ Kyoto University of Industrial Arts and Textile Fibers, Kyoto.
}

\begin{abstract}
The effects of water on the dye promoting efficiency of nonionic surfactants for polyethylene terephthalate dyeing with a disperse dye were studied, and the following results were obtained :

(1) Comparing with the hot air treatment, superheated steaming at atmospheric pressure gave much more rapid and high levels of fixation at the same temperature.

(2) Nonionic surfactants greatly accelerated the rate of dyeing and promoted the degree of fixation in both superheated steaming and hot air treatment.

(3) The behavior of disperse dye in the nonionic surfactant system containing a little water closely correlated with the quantity of water involved. The rate of diffussion and the partition coefficient increased with increasing the quantity of water, but the solubilities of dye in nonionic surfactant decreased with increasing the quantity of water.

\section{摘要}

(Recieved April 13, 1983)

目的 ポリエステル織維の分散染料による染色における濃染剤の効果に及ぼす水の影響について実験的に検討する.

結果 染料の固着媒体として過熱水蒸気と乾燥加熱空気とを比較した場合, 染着速度および平衡染着量とも前者が大きい.また 濃染剤としての非イオン活性剤の効果は両固着法とも優れるが, 特に前者の場合に大きい.つぎに非イオン活性剤を染色媒体とし て染色する場合，この系に水を添加すれば，その量の増加に伴って拡散係数および分配係数は増加するが，染料溶解度は低下する.
\end{abstract}

(昭和58年 4 月13日受理)

\section{1. 緒言}

各種の染料による染色では，染料の固着媒体として飽 和水蒸気, 過熱水蒸気, 乾燥加熱空気などが利用されて いるが，固着媒体中の水分量が減少するに伴って固着率 が低下し，濃色がえにくくなる．たとえばポリエステル 繊維の分散染料によるサーモゾル染色においても乾燥加 熱空気法よりも過熱水蒸気法の方が固着率が高く，また 固着速度が速い(1,2).この原因については明確な理由は示 されていないが, 布の昇温速度は凝縮水量の多い過熱水

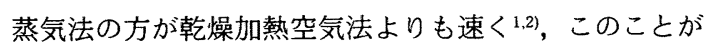
原因の 1 つであると考えられる.

過熱水蒸気法での凝縮水量は, 通常, 時間とともに大
きく変化するため染着性に及ぼす凝縮水の影響を定量的 に求めることは極めて困難である.

そこで本報では, 過熱水蒸気法での非イオン活性剤の 染色的挙動を乾燥加熱空気法と比較した後, 両者におけ る染着性の相違の原因を知るため非イオン活性剤に水を 加え, 活性剤の濃染効果に及ぼす水の影響を検討した.

\section{2. 赛験方法}

\section{1 試料および試薬}

繊維試料は, 既報と同一の ${ }^{3) \sim 5), ~ ホ ゚ リ エ ス テ ル タ フ ~}$ 夕(目付け $268 \mathrm{~g} / \mathrm{m}^{2}$ ) およびポリエチレンテレフタレー トフィルム (三菱樹脂製, 厚さ $16 \mu$, 密度 $1.403 \mathrm{~g} / \mathrm{cm}^{3}$ ) を使用した。フィルムは使用前にエーテルで洗浄し, 夾 
表 1 非イオン活性剤の構造と試料名

\begin{tabular}{c|c|c}
\hline \hline 化 & 試 学 料 名 & H L B \\
\hline ポリエチレングリコールアルキルフェニルエーテル & エマルジェト 100 & 18 造 \\
\hline ポリエチレングリコールノニルフェニルエーテル & ノイゲンE A 70 & 8 \\
& " E A 120 & 12 \\
& E A 140 & 14 \\
& E A 160 & 16 \\
\hline ポリエチレングリコールアルキルアリルエーテル & ノイゲンE A 137 & 13 \\
\hline ポリエチレングリコールドデシルフェニルエーテル & ノイゲンE A 143 & 14 \\
\hline ポリエチレングリコールトリデシルエーテル & ノイゲンE T 120 & 12 \\
\hline
\end{tabular}

雑物を除去したのち, 風乾し, デシケータ中に保存して 使用した。

染料は C. I. Disperse Red 143 の精製品および市販品 を使ったが，これらは既報引と同じ試料である。

非イオン活性剤は表 1 に示すものを使用したが, 必要 に応じて $105^{\circ} \mathrm{C}$ の恒温乾燥器で乾燥して使った。 また含 水量はカール フィッシャ法で測定した.

\section{2 潾染効果の測定}

捺染糊は元糊 $9.27 \mathrm{~g}$, 市販の染料 $0.5 \mathrm{~g}$, 非イオン活 性剂 $0.2 \mathrm{~g}$ ，クエン酸 $0.03 \mathrm{~g}$ の処方である. 元糊は市販 のラメクリスタル ガムを水に溶し, $300 \mathrm{~g} / \ell$ の濃度で 使用した。これらの条件は既報と同様である ${ }^{4,5)}$.

捺染糊は厚さ $0.1 \mathrm{~mm}$ の試験用スクリーン（100メッ シュ) でポリエステル タフタにゴムベらで往復印捺し, 風乾後，固着する．印捺量は湿潤時において布重量に対

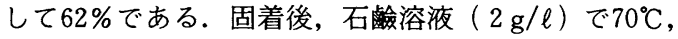
$5 \mathrm{~min}$ 処理し, 水洗, 乾燥する.

染色物の測色は日立カラーアナライザ307で行い, 染 色物の最大吸収波長での $K / S$ 值を算出し, 表面濃度と した.

\section{3 固着装置}

印捺後の染料固着はミニ スチーマ・“スチームペッ ト”(市金工業社製) を用いる。この試験機は熱源とし て $9.6 \mathrm{~kW}$ の電気ヒータと $4 \mathrm{~kg} / \mathrm{cm}^{2}$ の乾き飽和水蒸気 とが使われている.この試験機によって過熱水蒸気処理 および乾燥加熱空気処理を行った。

\section{4 拡散係数の測定}

所要量の水を含む非イオン活性剤溶液に精製染料を溶 解し, $10 \mathrm{~g} / \ell$ の染料溶液とする．この溶液を反転式高 温染色試験機（東亜精機製）に入れ，ポリエチレンテレ フタレートフィルム (以下 PET とする) を所定条件 で染色後, 取出し, 石䲓溶液で室温でよく洗い, ついで 水洗する. 染着量は染色フィルムを直接, 比色定量した. なお染料溶液 $1 \ell$ に対して PET は $0.8 \mathrm{~g}$ とする.

染料の染着性が低いため染色時に染料溶液の濃度変化 は起らない．また非イオン活性剤への染料の溶解度は極
めて高いため $10 \mathrm{~g} / \ell$ の染料溶液では不溶解物はみられ ない。

拡散係数は無限浴での平板中の拡散式から算出した6). なお予備実験の結果から拡散係数の濃度依存性は認めら れない。

\section{5 平衡染着量の測定}

2. 4 項に準じた方法で, 各条件に対する平衡染着量を 求める.すなわち所要量の水を含む非イオン活性剤溶液 に染料を溶解し, 反転式高温染色試験機で PET を染色 して, それぞれの条件での平衡染着量を求める.

\section{3. 結果と考察}

\section{1 過熱水蒸気法での非イオン活性㓮の効果}

過熱水蒸気法および乾燥加熱空気法での染着量に及ぼ す非イオン活性剤の影響は図 1 ～図 5 のようである。乾 燥加熱空気法での非イオン活性剤の影響については既報 で述べたが3゙ 5)，実験装置が変っても，その結果は同一 傾向を示し，非イオン活性剂は顕著な促染効果（濃染効 果)を示す。

これらの図からつぎの結論がえられる.

（1）過熱水蒸気法では, 乾燥加熱空気法と同様, 非亿 オン活性剤は促染効果がある.

（2）過熱水蒸気法は, 乾燥加熱空気法に比較して, 染 着速度および平衡染着量が大きい。

（3）非イオン活性剤の促染効果は，その種類によって 変るが, それらの差は活性剤の有無による差ほよ゙顕著で はない.

非イオン活性剤の促染効果の理由については既報で述 ベた3) -5).すなわち非イオン活性剤は分散染料の溶解力 が極めて顕著であり，また非イオン活性剤の使用量が極 めて少量であることから, 非イオン活性剤に濃厚に溶け た染料が繊維相に有効かつ迅速に移行するため染着量が 向上し，いわゆる濃染効果が得られる。

この現象は加熱媒体が過熱水蒸気でも乾燥加熱空気で も起こると考えられる.つまり両加熱媒体中の被染物は, 吸湿度に差はあるが，いずれも乾いた状態での固着過程 


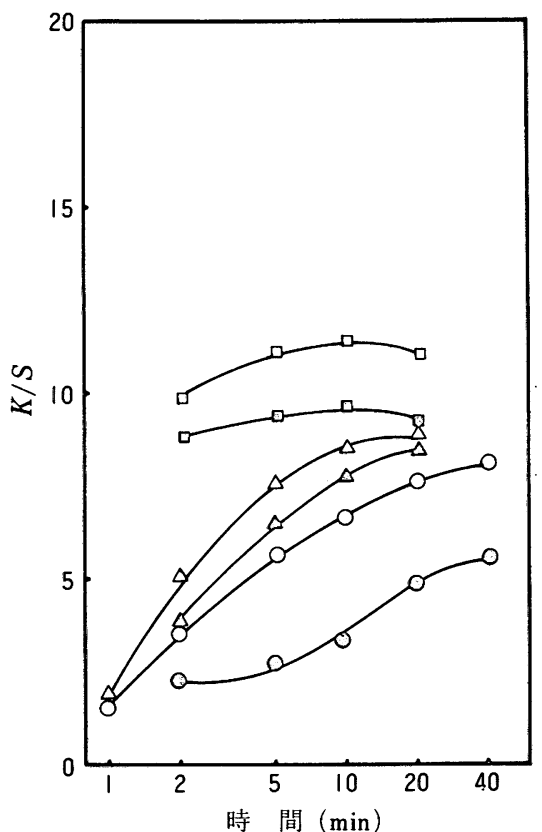

図 1 C. I. Disperse Red 143 の染着速度曲線（非 イオン活性風無添加)

乾燥加熱空気法 ( $(0, \Delta$, 圈), 過熱水蒸気法 $(\bigcirc$, $\triangle, \square)$

温度 : $160^{\circ} \mathrm{C}(\bigcirc, \bigcirc), 180^{\circ} \mathrm{C}(\Delta, \Delta), 200^{\circ} \mathrm{C}(\square$, 图)

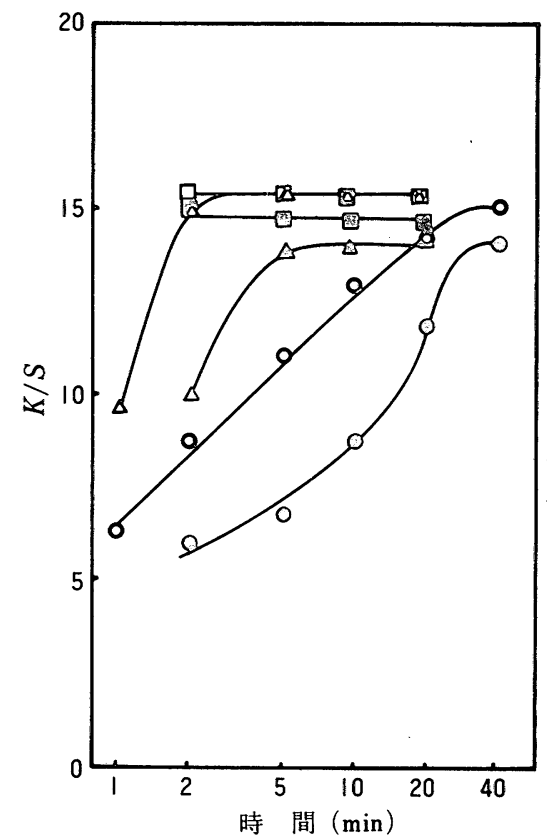

図 2 C. I. Disperse Red 143 の染着速度曲線（） イゲン EA 70 添加)

(符号は図 1 と同じ)

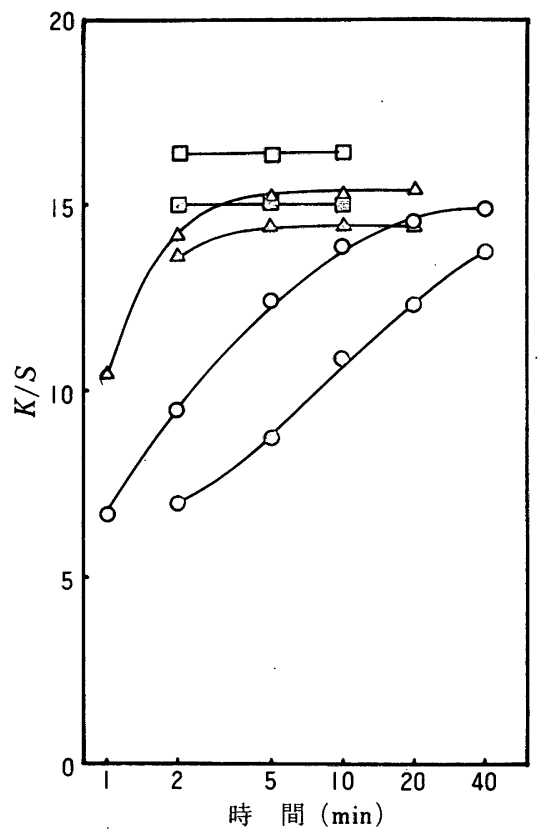

図 3 C. I. Disperse Red 143 の染着速度曲線（） イゲン EA 120 添加)

(符号は図 1 と同じ).

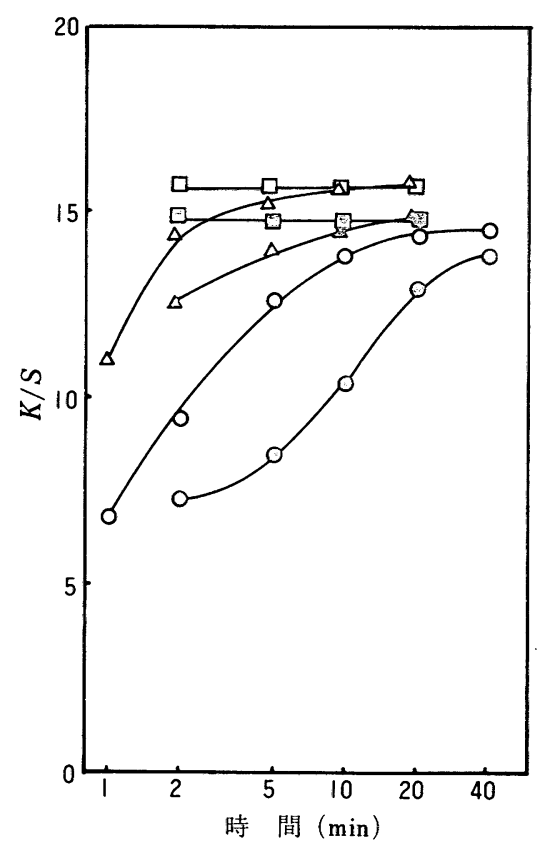

図 4 C. I. Disperse Red 143 の染着速度曲線（ノ イゲン EA 160 添加）

（符号は図 1 と同じ） 


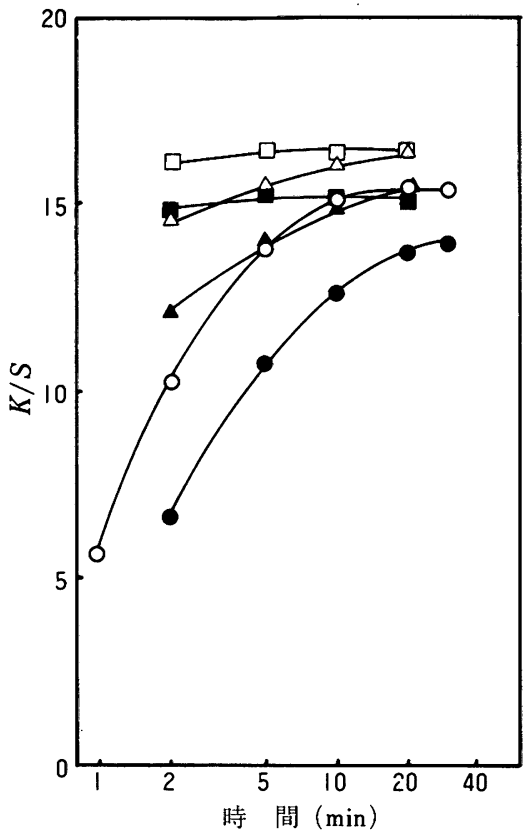

図 5 C. I. Disperse Red 143 の染着速度曲線（エ マルジット100添加)

(符号は図 1 と同じ)

であるため乾燥加熱空気法での非イオン活性風の濃染効 果は過熱水蒸気法でも起こると予測できる.

しかし過熱水蒸気法では, 非イオン活性風の有無にか かわらず, 乾燥加熱空気法よりも染着速度および平衡染 着量が常に大きい.

図 1 〜図 5 に基づき, $160^{\circ} \mathrm{C}$ での平衡染着量および半 染時間を求めると表 2 のようである. 表から分るように, 非イオン活性剤がなければ両固着法とも平衡染着量およ び染着速度は非常に低いが, 非イオン活性剂を加えれば 両固着法とも平衡染着量および染着速度は増加する．特 に過熱水蒸気法ではその効果が顕著である.このように 過熱水蒸気法が乾燥加熱空気法に比べて, 非イオン活性 剤の有無にかかわらず, 染色効果の優る理由としてつぎ の点が指摘できる.

（1）過熱水蒸気からの被染物への凝縮水量は飽和水蒸
気の場合とほほ同量である ${ }^{10)}$.

（2）水分凝縮による潜熱加熱時間の延長および凝縮水 分の再蒸発による恒率乾燥時間の延長ができる7.8).

（3）過熱水蒸気の伝熱係数は空気より大きい99.

すなわち過熱水蒸気からの凝縮水量は飽和水蒸気の場 合とほぼ同量で, 飽和水蒸気温度が $130^{\circ} \mathrm{C}$, 繊維の初め の温度が $20^{\circ} \mathrm{C}$ であれば凝縮水量は織維重量の約 $6 \%$ で あることが指摘されている(10). また2. 3 項の “スチーム ペット”では飽和水蒸気温度が $143^{\circ} \mathrm{C}\left(4 \mathrm{~kg} / \mathrm{cm}^{2}\right)$ であ るが, 過熱水蒸温度を $160^{\circ}, 180^{\circ}$ および $200^{\circ} \mathrm{C}$ とすれ ば, $20^{\circ} \mathrm{C}$ のポリエステル繊維への凝縮水量は, 堀川の 式から10)，それぞれ6.2，6.1および5.9\%となる.しか しこの凝縮水は極めて短時間のうちに気化するとされて (る10).

水の凝縮に伴う潜熱加熱は大きく, 被染物は迅速に昇 温される7,8). また凝縮水分の再蒸発による恒率乾燥時間 は凝縮水分の多いほど延長され, 被染物は水を含んだ状 態で恒率乾燥温度に保たれる。

これらのことから過熱永蒸気による固着では, その初 期段階での被染物の昇温速度は乾燥加熱空気よりも速 く，そのため染着速度の向上が考えられる.

また過熱水蒸気の伝熱係数 $\alpha$ を空気のそれ $\alpha^{*}$ と比較 した場合,

$$
\frac{\alpha}{\alpha^{*}}=\frac{\lambda}{\lambda^{*}} \cdot\left(\frac{a^{*}}{a}\right)^{0.78}
$$

で表わされる9).ここで $\lambda$ および $\lambda^{*}$ は熱伝導率， $a$ およ び $a^{*}$ は温度伝導率，*印は空気を表わす.

上式から $120^{\circ}, 160^{\circ}$ および $200^{\circ} \mathrm{C}$ での $\alpha / \alpha^{*}$ は 1.13 , 1.11および1.11であり, 過熱水蒸気の伝熱係数は空気の それより約 $10 \%$ 増加する.このことからすべての温度に ついて, 被染物への伝熱性は過熱水蒸気法の方が乾燥加 熱空気法よりも良好であり, その結果, 染着速度の向上 に寄与すると考えられる.

以上のように過熱水蒸気法は被染物の昇温速度の向上 に寄与する点から, 乾燥加熱空気法よりも染着速度の増 加をもたらすが，これらの理由からは平衡染着量の増加 表 2 C. I. Disperse Red 143 の染着性に及ぼす固着法および非イオン活性剤の影響 $\left(160^{\circ} \mathrm{C}\right)$

\begin{tabular}{|c|c|c|c|c|c|}
\hline \multirow{2}{*}{ 非 } & \multirow{2}{*}{ イオン 活 性 鼡 } & \multicolumn{2}{|c|}{ 平衡染着量（ $K / S$ 值） } & \multicolumn{2}{|c|}{ 半染時間 (min) } \\
\hline & & 乾燥加熱空気法 & 過熱水蒸気法 & 乾燥加熱空気法 & 過熱水蒸気法 \\
\hline & 無 添 加 & 5.5 & 8.0 & 4.0 & 2.5 \\
\hline & エマルジット 100 & 14.0 & 15.2 & 2.1 & 1.2 \\
\hline & ノイゲン E A 70 & 14.0 & 15.0 & 5.0 & 1.5 \\
\hline & " E A 120 & 14.0 & 15.0 & 2.0 & 1.2 \\
\hline & $"$ E A 140 & 14.1 & 15.0 & 3.5 & 1.5 \\
\hline & $"$ E A 160 & 13.8 & 14.6 & 2.0 & 1.1 \\
\hline & $"$ E A 137 & 13.5 & 14.0 & 2.4 & 1.1 \\
\hline & " E A 143 & 13.2 & 14.0 & 2.0 & 1.1 \\
\hline & " E T 120 & 14.0 & 15.5 & 4.0 & 1.3 \\
\hline
\end{tabular}


は説明できない，

ところで過熱水蒸気法と乾燥加熱空気法との 1 つの大 きな相違点は被染物への凝縮水の有無であるが, 過熱水 蒸気法での水の凝縮は過渡的現象であり, そのため凝縮 水量と染着性との関係を定量的に取扱うことは極めて困 難である. そこで水の挙動を知るためには非イオン活性 剤に一定量の水を添加し, 非イオン活性剤の濃染効果に 及ぼす水の影響を調べるのが 1 つの方法であると考え, 次項以下でこのことを検討した。

\section{2 非イオン活性剤系での拡散這度に及ぼす水の影} 整

非イオン活性剤としてノイゲン EA 120 を用い, PET へ C. I. Disperse Red 143 の染着速度に及ぼす 水分量の影響を求めると図 6 のようである.この結果か ら拡散係数を算出し, 温度との関係を図示すると図 7 の ようである. これらの結果からわかるように, 水添加量 の増加に伴って拡散係数は増加する.すなわち図 8 に示 すように非イオン活性剤に対して水を $100 \mathrm{~m} \ell / \ell$ 加えれ ば拡散係数は水無添加の約 2 倍に増加するが, 水添 加量の増加に伴なって拡散係数の増加効果は減少する傾 向がみられる.

ポリエステル繊維への分散染料の拡散係数に及ぼす水 の影響は, 吸水量または吸湿量の増加によるガラス転移 温度の低下およびそれに伴う染料の拡散係数の増加によ

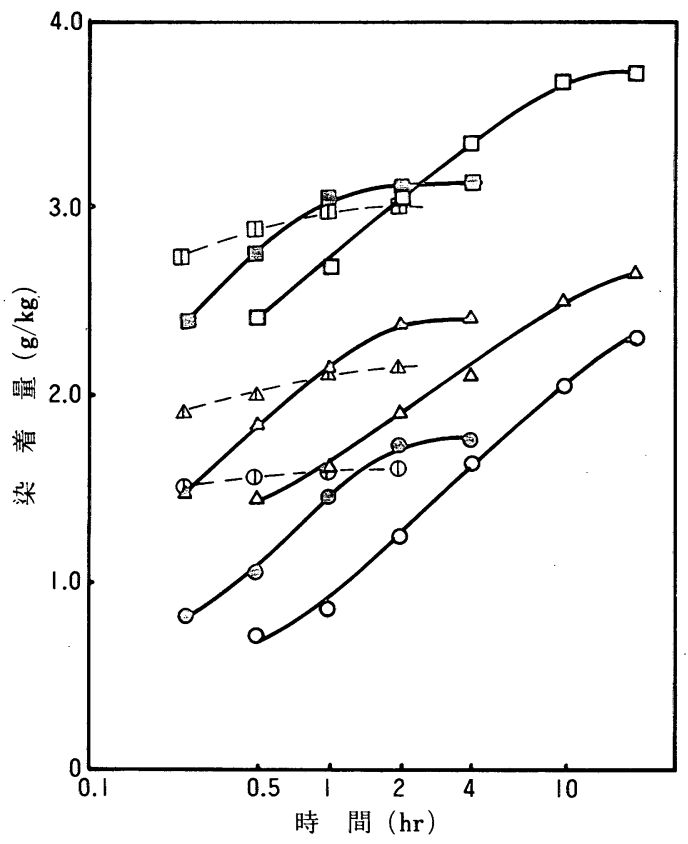

図 6 ノイゲン EA 120 染浴からの C. I. Disperse Red 143 の染着速度曲線 (染料濃度 $10 \mathrm{~g} / \ell$ ) 水添加量 : $0 \mathrm{~m} \ell / \ell(\bigcirc, \Phi, \bigcirc), 100 \mathrm{~m} \ell / \ell(\Delta, 4$,

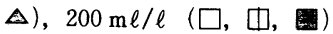

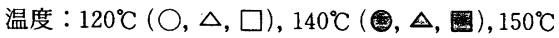
(Ф, 4, 由)

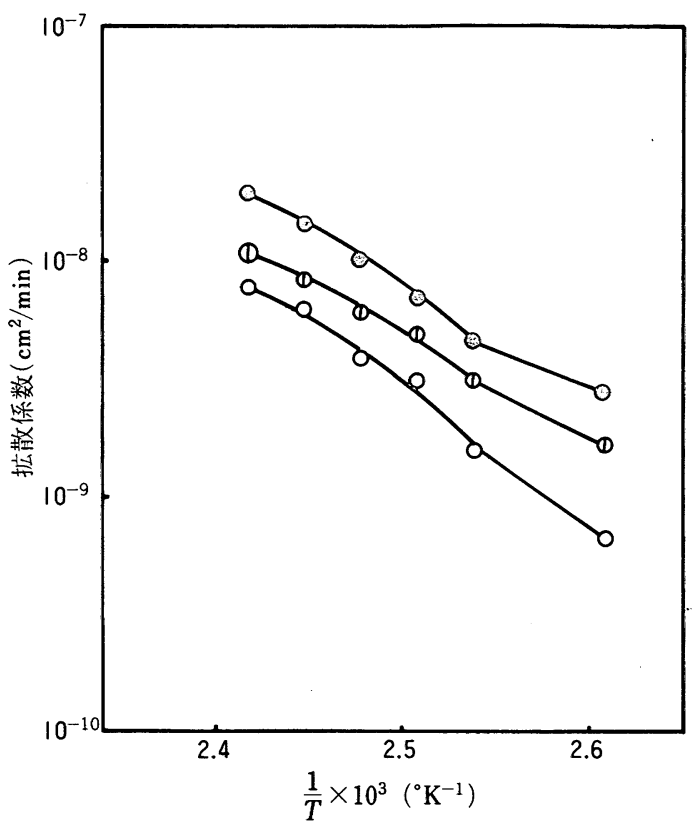

図 7 ノイゲン EA 120 染浴からの C. I. Disperse Red 143 の拡散係数と温度との関係 水添加量 $: 0 \mathrm{~m} \ell / \ell(\bigcirc), 100 \mathrm{~m} \ell / \ell($ (D), $200 \mathrm{~m} \ell$ $1 \ell$ (2)

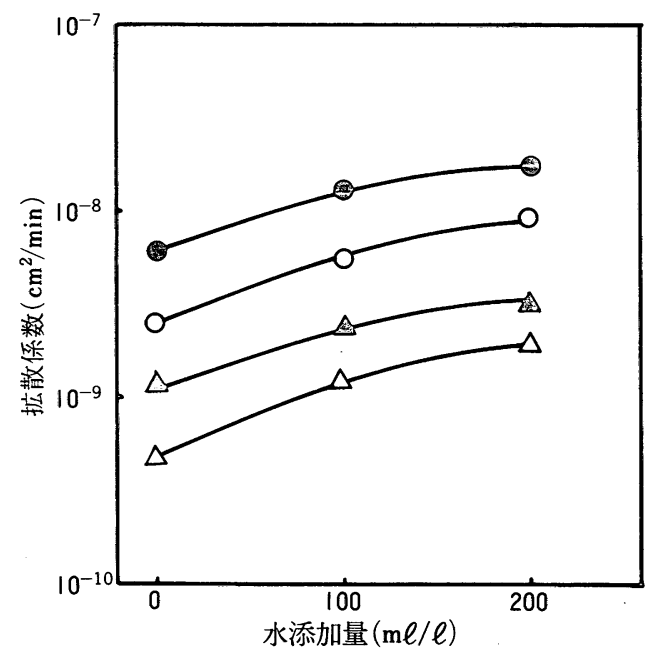

図 8 ノイゲン EA 120 染浴からの C. I. Disperse Red 143 の拡散係数に与える水添加量の影響 温度 : $110^{\circ} \mathrm{C}(\Delta), 120^{\circ} \mathrm{C}(\Delta), 130^{\circ} \mathrm{C}(\mathrm{O}), 140^{\circ} \mathrm{C}$ (구)

って説明できる11,12). しかし本研究のように吸水量が非 常に低いと思われる場合のガラス転移温度との関係につ いては更に詳細な検討が必要である.

3. 1 項で示した, 過熱水蒸気法での染着速度が乾燥加 熱空気法よりも常に大きい理由として，水の凝縮による 潜熱加熱や伝熱係数の増加などによる昇温速度の増加の ほかに，本項で示したように凝縮水または吸湿による水 分が染料の繊維への拡散係数を増加して染着速度を速め 
ることも考えられる.

\section{3 非イオン活性剤系での平衔染着量に及ぼす水の 影慗}

非イオン活性剤としてノイゲン EA 120 を用い, PET への C. I. Disperse Red 143 の平衡染着量に及ぼ す水分量の影響は図 9 および図10のようである．また非 イオン活性剤系での等温吸着曲線に及ぼす水の影響は図 11のようである.これらの結果からつぎの結論がえられ る.

（1）染料濃度および温度が一定であれば，平衡染着量 は水添加量の増加に伴って増加する.

（2）等温吸着曲線は分配則に従う．その際，分配係数 は水系に比べて非常に低いが，水添加量の増加に伴って 増加する。

（3）飽和染着量は温度および水添加量によって変化す .るが, 一定温度での飽和染着量は水添加量の増加に伴っ て減少する。

（4）溶解度は水添加量の増加に伴ってかなり大きく低 下する.

等温吸着曲線が分配則に従う場合, 分配係数と飽和染 着量とがわかれば溶解度が算出できる．各条件での溶解 度は表 3 のようであり, 温度が一定の場合, 溶解度は水 添加量の増加に伴ってかなり大きく減少する．このよう に水添加による溶解度の減少は染料の繊維相への移行性 を促進し，分配係数の増加をもたらす。このため図13お よび表 3 に示すように, 分配係数は水添加量の増加に伴 って増加するが，水系での分配係数に比べればいずれも 非常に低(13).

すなわち溶解度は水添加によって減少したとはいえ，

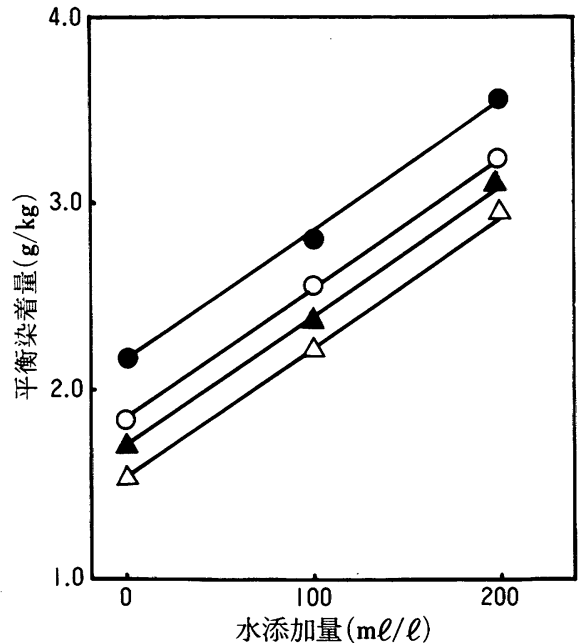

図 9 ノイゲン EA 120 染浴からの C. I. Disperse Red 143 の平衡染着量に与える水添加量の影 響 (染料濃度 $10 \mathrm{~g} / \ell$ )

温度 : $120^{\circ} \mathrm{C}(\mathbf{O}), 130^{\circ} \mathrm{C}(\mathrm{O}), 140^{\circ} \mathrm{C}(\boldsymbol{\Delta}), 150^{\circ} \mathrm{C}$ $(\Delta)$

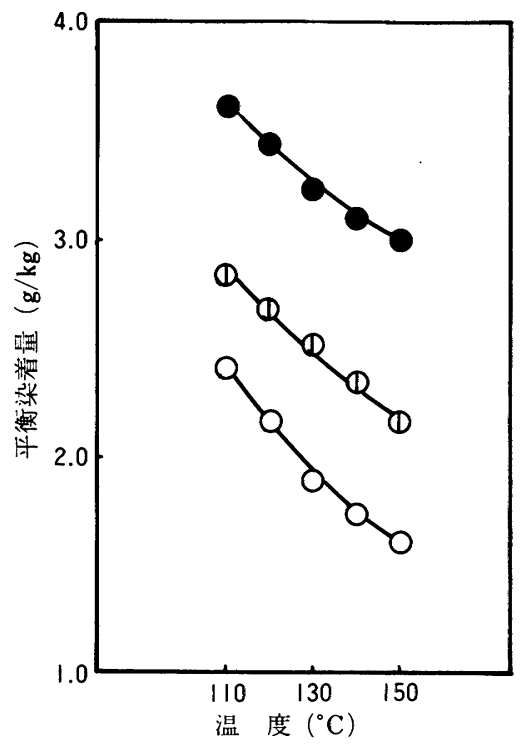

図10 ノイゲン EA 120 染浴からの C. I. Disperse Red 143 の平衡染着量に与える温度の影響 (染料濃度 $10 \mathrm{~g} / \ell$ )

水添加量 : $0 \mathrm{~m} \ell / \ell(\mathrm{O}), 100 \mathrm{~m} \ell / \ell(D), 200 \mathrm{~m} \ell$ le

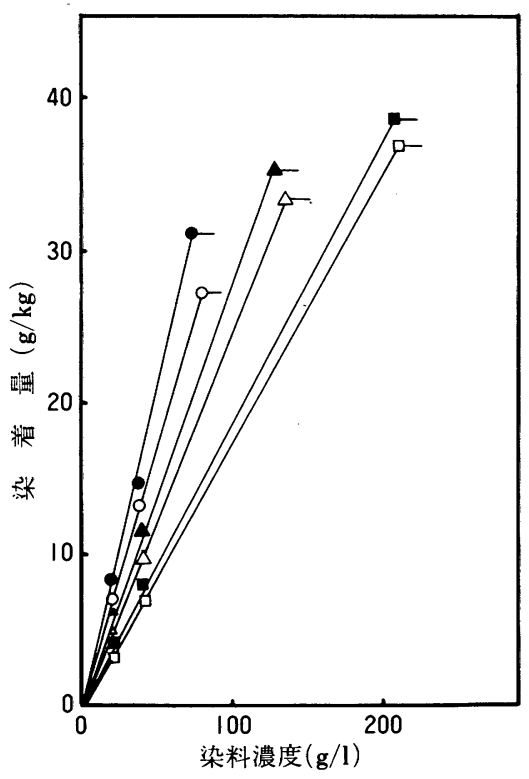

図11 ノイゲン EA 120 染浴からの C. I. Disperse Red 143 の等温吸着曲線

水添加量 : $0 \mathrm{~m} \ell / \ell(\square, \boldsymbol{\square}), 100 \mathrm{~m} \ell / \ell(\Delta, \Delta)$, $200 \mathrm{~m} \ell / \ell(\mathrm{O}$,

温度 $: 130^{\circ} \mathrm{C}(\square, \Delta, \bullet), 150^{\circ} \mathrm{C}(\square, \Delta, \mathrm{O})$

精製染料の水への溶解度に比べて, 約 $10^{2} \sim 10^{4}$ 倍であ $\eta^{13)}$ ，著しく大きい，このため水系での分配係数に比べ て，水を含む非イオン活性剤での分配係数は非常に小さ く, 約 $10^{-3} \sim 10^{-4}$ 倍である ${ }^{13)}$.

一方, 飽和染着量は水系でのそれにほぼ相当する が14,15)，水添加量の増加に伴って表 3 のようにわずかに 
表 3 ノイゲンEA120染浴からの C.I.Disperse Red143 のPET への分配係数, 飽和染着量 および染浴での染料溶解度

\begin{tabular}{c|c|c|c|c}
\hline \hline \multirow{2}{*}{ 諸 特 性 } & \multirow{2}{*}{ 温度 } & \multicolumn{3}{|c}{ 水添加量 $(\mathrm{m} \ell / \ell)$} \\
\cline { 3 - 5 } & & 0 & 100 & 200 \\
\hline \multirow{2}{*}{ 分配 係数 $(\ell / \mathrm{kg})$} & $130^{\circ} \mathrm{C}$ & 0.196 & 0.260 & 0.364 \\
& $150^{\circ} \mathrm{C}$ & 0.183 & 0.234 & 0.304 \\
\hline \multirow{2}{*}{ 飽和染着量 $(\mathrm{g} / \mathrm{kg})$} & $130^{\circ} \mathrm{C}$ & 38.8 & 35.3 & 32.2 \\
& $150^{\circ} \mathrm{C}$ & 36.6 & 33.3 & 27.1 \\
\hline \multirow{2}{*}{ 溶 解 度 $(\mathrm{g} / \ell)$} & $130^{\circ} \mathrm{C}$ & 198.0 & 135.8 & 88.5 \\
& $150^{\circ} \mathrm{C}$ & 200.0 & 142.3 & 89.1 \\
\hline
\end{tabular}

減少する.

以上のことから非イオン活性剤系に水が少量含まれれ ば, 非イオン活性剤への染料の溶解度が低下し, 分配係 数が向上する. また一定濃度での平衡染着量は分配係数 の増加に応じて増加する.

3. 1 項で示した過熱水蒸気法での染着量が乾燥加熱空 気法よりも常に大きい理由として，凝縮水または吸湿に よる水分が染料の繊維への移行に直接関与するか, 非イ オン活性剤に吸収された水分として上記の機構にもとづ いて染着性を促進すると考えられる．ただ水分が染料の 繊維への移行に直接関与する機構については更に詳細な 検討が必要である.

\section{4. 結 論}

非イオン活性風の促染 (濃染) 効果に及ぼす水の影響 について検討した結果, つぎのことが結論できる.
（1）過熱水蒸気法で固着する場合の染着速度および染 着量は乾燥加熱空気法よりも大きい.

（2）過熱水蒸気法での非イオン活性剤の濃染効果は乾 燥加熱空気法と同様に非常に大きい.

（3）非イオン活性剤系での PET への分散染料の拡散 係数は, 系への水添加量の増加に伴って増加する.

（4）非イオン活性剤系での PET への分散染料の等温 吸着曲線は分配則に従う.そして分配係数は非常に小さ いが，水添加量の増加に伴って増加する.

（5）非イオン活性剤系での分散染料の溶解度は非常に 大きいが，水添加量の増加に伴って減少する.

（6）飽和染着量は大きいが, 水添加量の影響は小さい. 文献

1) P. Ulrich, H. P. Schaul ; SVF-Fachorg, 20, 711 (1965)

2) P. Ulrich, H. Niederer ; Textilver., 1, 228 (1966)

3）橋本勇; 緘機誌, 34, T 172 (1981)

4) 橋本勇; 織機誌, 34, T 194 (1981)

5) 橋本勇; 織機誌, 34, T209 (1981)

6) 黒木宣彦; 染色理論化学, 108 109ページ（昭41）

7) A. P. Lockett ; J. Soc. Dyers Col., 83, 6 (1967)

8) 脇田登美司; 緉学誌, 30, T 319 (1974)

9）村上文男; 基礎瀻維工学（V)，329ページ（昭46）

10）堀川明; 日本緎維機械学会, 講演論文集, No. 21, 177ペー ジ (昭43)

11）喜多村一夫, 吉田三郎, 椿茂雄 ; 日化, 1972, 2219

12) 橋本勇; 織学誌, 34, T 225 (1978)

13）橋本勇; 織機誌, 27, T 150 (1974)

14) O. Glenz, W. Beckmann, W. Wunder ; J. Soc. Dyers Col., 75, 141 (1959)

15) M. J. Schuler, W. R. Remington; Discussion Faraday Soc., No. 16, 201 (1954) 